\title{
Kinase assays
}

June Round

\section{Method Article}

Keywords: kinase

Posted Date: January 29th, 2007

DOl: https://doi.org/10.1038/nprot.2007.67

License: (c) (i) This work is licensed under a Creative Commons Attribution 4.0 International License. Read Full License 


\section{Abstract}

\section{Introduction}

This protocol was used in the above_Nature Immunology_ paper.

\section{Procedure}

1. Stimulate $10-20 \times 10^{6}$ OT- 1 hybridoma T cells by incubating $5 \mathrm{ug} / \mathrm{ml} / 5 \times 10^{7}$ cells of anti-CD3 $\backslash(2 \mathrm{C} 11$,

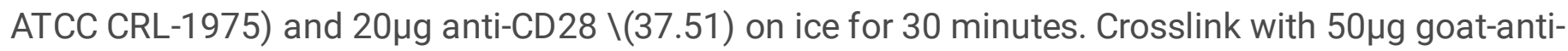

hamster antibody $\backslash(\mathrm{MP}$ Biomedicals 55394$)$ at $37^{\circ} \mathrm{C}$ for 30 minutes $\backslash\left(\right.$ keeping cells at $\left.5 \times 10^{7} / \mathrm{ml}\right)$. 2. Lyse cells in TNE $\backslash(50 \mathrm{mM}$ Tris $\backslash(\mathrm{pH} 7.5), 150 \mathrm{mM} \mathrm{NaCl}, 1 \mathrm{mM}$ EDTA, $1 \mu \mathrm{g} / \mathrm{ml}$ aprotinin, $1 \mu \mathrm{g} / \mathrm{ml}$ leupeptin, 1 mM PMSF, and 1-5 $\mathrm{mM} \mathrm{Na}_{3} \mathrm{VO}_{4}$. Clear lysates by centrifugation at $12,000 \mathrm{Xg}$ for 10 minutes at $4^{\circ} \mathrm{C}$. 3 . Set up immunopreciptations of Dlgh1 using $40 \mu$ of protein $\mathrm{G} \backslash(50 \%$ slurry so $20 \mu$ l bead volume) $\backslash(\mathrm{GE}$ Healthcare Bio-Sciences 17-0618-02) and $10 \mu \mathrm{l} \backslash(2.5 \mu \mathrm{g})$ of DIgh1 \(BD Transduction Lab 610875) or p38 $\backslash(2.0 \mu \mathrm{g}) \backslash($ Santa Cruz, C-20, sc-535) antibody. Tumble at $4 \mathrm{uC}$ for 1-2 hours. Save some of this supernatant to check efficiency of IP. 4. Wash once with $500 \mu$ l of kinase buffer $\backslash(25 \mathrm{mM}$ Tris pH 7.5, $5 \mathrm{mM}$ B-glycerophosphate, $2 \mathrm{mM} \mathrm{DTT}, 0.1 \mathrm{mM} \mathrm{Na}_{3} \mathrm{VO}_{4}$ and $10 \mathrm{mM} \mathrm{MgCL}_{2}$; Cell signaling 9802) 5. In a final volume of $50 \mu \mathrm{l}$ have $1 \mu \mathrm{g}$ of GST-ATF2 $\backslash$ (Cell signaling, $9224 \mathrm{~S}$ ) and/or $50 \mu \mathrm{M}$ unlabeled ATP $\backslash$ (Cell signaling, 9804) with immunopreciptates in kinase buffer. $\backslash(20 \mu \mathrm{l}$ of beads, $1 \mu \mathrm{l}$ of ATP, $29 \mu \mathrm{l}$ of kinase buffer) MAKE SURE TO DO ALL OF THIS ON ICE 6 . Incubate at $30^{\circ} \mathrm{C}$ for $5-20$ minutes. 7 . Add $20 \mu \mathrm{I} 5 \mathrm{X}$ Loading buffer to stop reaction and boil for 5 minutes 